\title{
THE PSYCHOTHERAPEUTIC ROLE OF THE NURSE IN A PSYCHODYNAMIC UNIT
}

GAIL LUIZ RICCITELLI Nurs. (Rand., R.N., R.M., R.P.N., (Tara) ELIZABETH LOMBARD R.N., R.M., R.P.N., (Groote Schuur Hospital) PSYCHIATRIC NURSES DEPARTMENT OF PSYCHIATRY GROO'TE SCHUUR HOSPITAL

\section{OPSOMMING}

Daar is alreeds oor die belangrikheid van terapeutiese gemeenskappe in die praktiese toepassing van psigiatrie geskryf. Die doel van hierdie artikel is om te illustreer in watter mate die rol van die psigiatriese verpleegkundige as terapeut in 'n terapeutiese gemeenskap ontwikkel het. Deur die inagneming van aspekte soos byvoorbeeld terapeutiese en dinamiese interaksie, terapeutiese inmenging op ' $n$ persoonlike basis, groeps- en gemeenskapswerk, met spesifieke verwysing na die verpleegkundige, word daar gehoop om die leser se aandag te vestig op die moontlikhede vir die verpleegkundige wat gewillig is om haar rol van versorger prys te gee en die rol van terapeut te aanvaar.

Die mening word uitgespreek dat die rol van die verpleegkundige in dié eenheid toegelaat is om so te ontwikkel as gevolg van 'n kombinasie van hoogs gemotiveerde voorgangers en die entoesiasme van die leier van die eenheid, wie se vertroue in die bevoegdheid van die psigiatriese verpleegkundiges gedien het as aansporing vir die ontwikkeling van die verpleegkundiges as terapeute. In aansluiting hierby is die aanvaarding van die verpleegk undige deur die ander lede van die groep as ' $n$ terapeut in haar eie reg, 'n voorvereiste.

\section{INTRODUCTION}

A great deal has been written on the importance of therapeutic communities in the practise of psychiatry. This article proposes to highlight the extent to which the role of the psychiatric nurse has been developed in such a community. By considering aspects such as therapeutic dynamics, therapeutic intervention on an individual basis, group work and community work with specific reference to the nurse, attention will be drawn to the avenues which are open to the nurse, who is willing te relinquish her role as custodian and don the cloak of therapist.

The role of the nurse in administration and education is as important as her therapeutic role but the focus will not be on these aspects. It must further be clearly stated that the description of the nurses' role does not include preand post-admission community care as this important facet of patient care warrants an article of its own.

The psychodynamic unit which is described is a ward in a large academic hospital. The ward caters for seventeen to a maximum of twenty in-patients and a maximum of five day patients. Most of the patients are adults of both sexes, although patients from 10 years up to the age of 65 are accepted. The majority of the patients are drawn from the middle class and have at least secondary education.

The ward offers two important psychiatric services, namely assessment and treatment. Although the focus of this article is on treatment, it is necessary to mention that a significant number of patients are referred for assessment. These are patients who require thorough medical and psychiatric investigation and who can, of necessity, be contained in an open ward

The therapeutic programme of the ward (see diagram 1) caters for a wide range of psychiatric problems of which the majority fall into the categories of neurotic conflicts, personality disorders, anorexia nervosa and depression (which constitutes $50 \%$ of the admissions). As the ward is open and all the patients are admitted voluntarily, the grossly psychotic and severely suicidal cannot be admitted. The unit is staffed by a multi-disciplinary therapeutic team (see diagram 2). Although the role of the nurse is under discussion it must be stressed that the very essence of team work denotes many grey areas where the functions of members of the team overlap.

In $1967 \mathrm{H}$. Moross published an article on the therapeutic community at Tara Hospital on which the philosophy of the ward under discussion is based.' The approach of the unit is essentially eclectic, including amongst others such theoretical frameworks as that of psychoanalysis, (Freud and Klein), as well as behaviourism (including social learning theory) and the Gestalt and Systems theories. Specific therapies based on these theoretical orientations may be used to meet the individual needs of patients.

The aim of the ward as a therapeutic community is to create a mini community, not unlike a large family unit, which provides the optimum conditions for the patient to learn new adaptive behaviour. In this environment the patient feels safe to experiment with his new behaviour and to explore aspects of himself, thus

facilitating greater self-awareness. The ultimate goal of this growth facilitating programme is to reduce the risk of relapse of psychiatric illness by decreasing vulnerability and enabling the patient to live up to his maximum potential. 


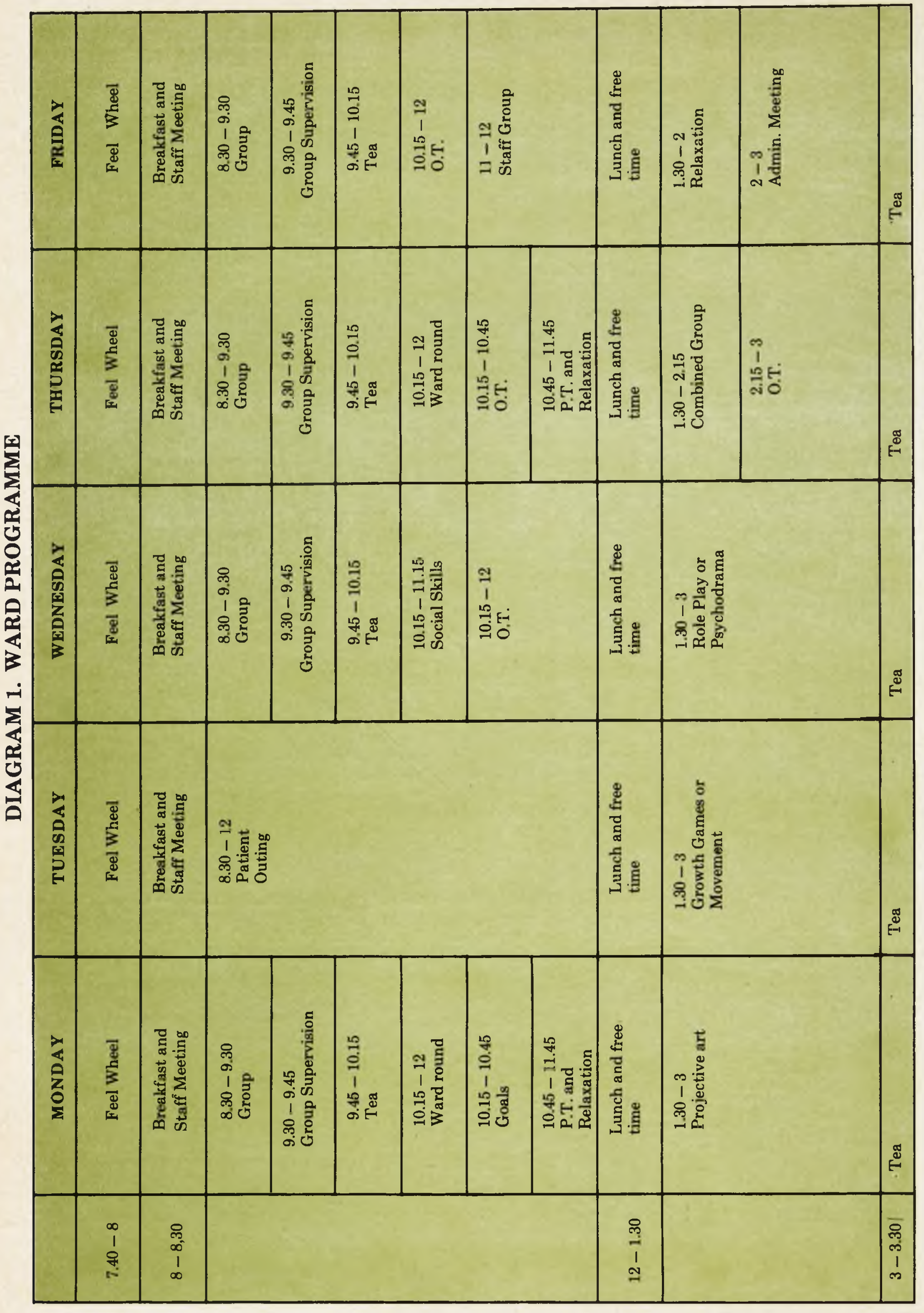




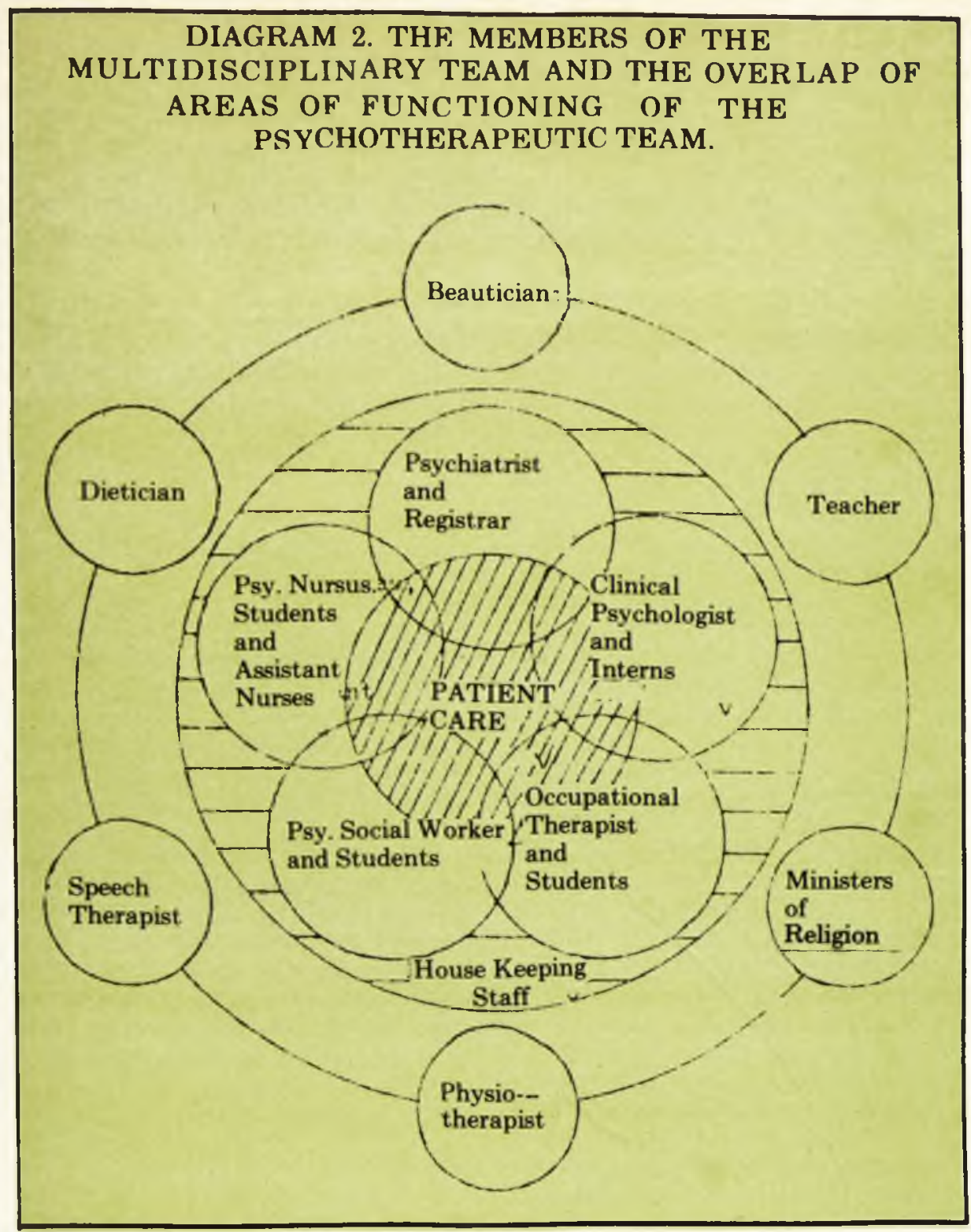

THERAPEUTIC DYNAMICS

It has been said that the most essential tool of the psychiatric nurse is the nurse herself. In a psychodynamic unit the implications of such a statement are far-reaching. Before describing the role of the nurse in ward activities it is necessary to consider the underlying dynamics of her relationships with the patients, particularly with regard to transference phenomena. Transference is the term used for the process whereby the patient's attitudes, formerly expressed or felt towards another significant person in his life, are projected or transferred onto the therapist who, in this instance, is the nurse. ${ }^{3}$

In accordance with Sundine's classification $^{12}$ therapeutic dynamics is divided into the pre-interaction, orientation, working and termination phases.

\section{Pre-interaction phase}

The relationship between the nurse and the patient constitutes the principal means for eliciting, recognising and handling significant feelings and ideas in order to change the patient's behaviour. It is therefore essential for the nurse to have an awareness of herself, coupled with an ability to form satisfactory relationships. Using her awareness of self she should strive to maximise her strengths and assets and minimise her limitations. This selfknowledge may be obtained by selfanalysis, peer-review, professional supervision and feed-back. The latter may be given formally during handover or a ward round or informally at staff-groups or during the tea break. Care is thus taken to allow the nurse the opportunity to explore useful insights into her professional role. As the nurse is also an important have a reasonably stable self-concept and an adequate amount of self-esteem. She should be able to face reality and help patients to do likewise.

In addition to what may be described as having an integrated personality, the nurse also requires a sound theoretical knowledge in order her feelings and fears and to develop role model for the patients, she should to utilise the phenomena to be described in a therapeutic manner.

\section{Orientation phase}

First impressions are important in determining the patient's adjustment to the ward. As the nurse is the first team member to come into contact with the patient she should anticipate that the patient will be influenced by her verbal and non-verbal (body language, uniform) communication. It is the nurse who monitors the patient's adjustment to the physical environment as well as the ward programme and who gives the support which is required so often.

It has been observed that on admission many patients tend to regress and relinquish all responsibility for their treatment. Signs of regression may be evident in the patient's attitude to the physical environment of the ward or to the staff and the community as a whole. He may resort to the primitive defence mechanism of splitting and projecting bad and good aspects of the self onto members of the staff. The nurse may thus be seen as 'n persecutor and a bad object or alternatively as an idealised, good object.

It is essential for the nurse to understand this transference phenomenon if she is to remain therapeutic and not become enmeshed in the patient's pathology by being offended by attacks and becoming defensive, or by considering herself the only one who understands, as professed by the patient.

A patient in such a state of regression will not hesitate to exploit any members of the team and each member should be careful not to fall into the trap of unconsciously colluding with the patient.

\section{Working phase}

As therapy progresses the patient will gradually begin to perceive and relate to the staff and others as whole persons. However, transference phenomena will continue to evolve Such responses may be triggered by a superficial similarity such as a facial expression or manner of speech, or the nurse may be perceived by the patient as an figure of authority from the past, such as a parent, or a lost love object such as a former spouse. Such transference reactions are beneficial to the therepeutic process only if recognised and explored. ${ }^{2}$ Sooner or later patients indentify with members of the staff, hence the importance of their being authentic role models.

\section{Termination phase}

By means of transference the com munity may have become a family to patients who have established parental and sibling figures in their relationships with the staff and other patients. 
When discharge is planned, the patient must gradually disengage himself. The nurse should encourage him to do so by making him aware of his dependency and by helping him to establish outside contacts in his bid for autonomy. The nurse's constant feedback to the patient, is invaluable in helping him to improve his self-concept and gain independence, thus enabling effective termination.

\section{THERAPEUTIC INTERVENTION ON AN INDIVIDUAL BASIS}

On admission each patient is thoroughly assessed by the team and short and long term treatment goals are established. The ward programme is flexible and is modified to meet the needs of individual patients where possible. However, there are certain patient needs which are not catered for in the programme or in individual psychotherapy and which are essentially the nurse's responsibility.

Firstly, if the team decides that a patient requires a special programme to facilitate specific aspects of therapy a nurse will be allocated to, and be responsible for, such a programme. The nurse, in accordance with the principles of the nursing process, will assess her special patient's needs with the assistance of the team, plan a programme with the patient and also carry the responsibility for its implementation. At various stages of the patient's treatment, she will need to reassess his progress with the team and make adjustments accordingly.

Secondly, the nurse is responsible for meeting patient's needs after hours and outside of planned activities, particularly in the event of a crisis.

\section{Behaviour modification pro- grammes}

It must be stressed that behaviour modification programmes are only aspects of therapy. Their value lies in facilitating the extensive psychotherapy offered by the ward programme. It is the philosophy of the unit to combine behaviour modification programmes (where prescribed) with psychotherapy to attain the goal of change in the functional relationships which maintain sick behaviour.

\section{The anorectic patient}

The behaviour modification programme for anorectic patients, which utilises operant conditioning based on a privilege system, has proved a remarkable means of attaining the immediate goal of restoring weight gain. A nurse is allocated to special the patient from the day of admission until discharge. It is her responsibility to compile the list of privileges to be earned and plan a menu in consultation with the patient and dietician for each phase of treatment.

A consistently firm approach is essential to the success of such a programme. Being manipulated by the patient to bend the rules can prove detrimental to treatment.

The nurse is faced with the dilemma of no longer conforming to her traditional role of the all-giving, all-pleasing good mother; to remain therapeutic in this instance she must be able to frustrate her patient's desires where necessary. On numerous occasions such as when the patient has a privilege removed for not having conformed to the programme, the nurse is the object of negative projections and becomes the bad mother. It is thus essential that the nurse has open and direct communication and feedback with the patient's individual psychotherapist. 'This is necessary in spite of the fact that the behaviour modification programme is entirely separate from psychotherapy (the patient's individual psychotherapist never discusses details of the programme with the patient).

Other nurses must ensure that the patient adheres to the programme 24 hours a day. For this purpose up-todate charts and menus are kept as guides. Initially, food intake and weight gain is controlled by the nurse, but treatment is geared towards the patient taking increasing responsibility for herself until she shows signs of being able to function autonomously.

\section{The obsessive compulsive pa- tient}

Where a patient's social functioning is hampered by his neurosis a behaviour modification programme may be prescribed by the team. An example of this phenomenon is when the patient refuses to eat certain foods or to change his clothes as part of his ritualistic behaviour. If these symptoms are not checked, the patient will suffer ill health as a result of poor nutrition or lack of hygiene.

A programme utilising operant conditioning based on a reward system is useful in treating such symptomatic behaviour. Once again it is the nurse who is responsible, together with the patient, for implementing the programme.

\section{The adolescent patient}

The adolescent who is faced with the difficult task of coping with emotional and physical changes, changing attitudes and establishing an identity of- ten has difficulty in coping with the demands of the ward programme.

In addition, the adolescent will attend the hospital school for a short time each day whenever possible. The nurse may assist the adolescent in structuring his time when he is not able to do so himself. A time table for after hours activities is very useful. Should the adolescent repeatedly display acting-out behaviour, it may be necessary for the nurse to implement a behaviour modification programme. She also allocates time for discussing issues of particular relevance to the adolescent, such as sexuality and dating.

\section{Mothers with their children}

Illness in a mother, particularly when centred on the mother-baby relationship, cannot be treated by separating her from her baby when admitting her to hospital. The positive outcome of admitting both mother and baby has been proven in research and is extremely rewarding in practice. ${ }^{2}$

On admission of a mother and baby to the ward, a nurse is allocated to care for them. The nurse must guard against taking over the care of the baby, advising or instructing, as this will reinforce the mother's feelings of inadequacy. Instead, the nurse must guide the mother in caring for the baby by positively reinforcing good mothering with approval and praise and also by acting as a role model for the mother. Sometimes it is necessary to do this by being a good mother to the patient as the mother's fears often arise out of a deprived childhood and having been mothered inadequately herself.

In meeting the emotional and physical needs of the mother and baby, the nurse utilises her skills as a midwife as well as those of a psychiatric nurse.

\section{Crisis intervention}

The nurse is with the patient around the clock and one of her duties is to provide a constant vigilance for signs of self-destructive behaviour.

Using her theoretical knowledge and observational skills the nurse intervenes in many crisis situations by giving support to the patient and avoiding the outcomes of impulsive behaviour such as acting out, running away and sometimes suicide. Every precaution, such as ensuring that all windows are locked, sharp objects are removed and medication is given on admission, is taken on the ward to eliminate environmental hazards. In the event of a patient harming himself it is the nurse 
who is usually on the spot to administer to the sometimes life-threatening needs of the patient.

\section{GROUP WORK}

Group work is a shared function of the multi-disciplinary team. As a therapist in the group work situation the nurse requires the skill to act as a leader or co-leader in the various types of group activities. She must be able to overcome her own narcissistic selfinterests in the working together process in order to avoid power struggles for leadership, a situation often unconsciously evoked by patient projections. Honest sharing of feelings with her co-therapist is necessary to establish a working relationship.

Group activities are a valuable source of clinical data and are invaluable to the patient's individual psychotherapist and to the work of the team as a whole. However, this is true only where the team is involved in the planning of the focus of these activities in order to meet the needs of the patient community, and if there is constant feedback to the rest of the team. Time is allocated for feedback and planning immediately after the group sessions, at ward rounds and morning meetings. In addition, supervision to facilitate the professional growth of the nurse and other therapists in group work is an on-going process made possible by the use of one-way mirrors and video tapes.

\section{Group therapy}

Traditionally the term group therapy is used to describe a branch of psychotherapy in which six to eight patients attend a specific number of meetings conducted by a therapist. The nurse must be able to utilise the group method and group process in treating the psychopathologies of the patients in the group.

Since group therapy is an important aspect of treatment the patient first observes the orientation group through the one way mirror, and gets to know the other group members before actually entering the group. In this group the emphasis is educational in the sense of learning a psychological language to understand symptoms and body language and learning to talk about feelings. When the patient has reached the stage of wanting to talk about key past relationships, memories or dreams, she moves to the working group where there is a more in-depth approach using a psycho-analytic model.

Group therapy has been effective in helping individuals establish more successful relationships by encouraging them to relate to other people in the group and to resolve some of their former problems and conflicts. An im. portant by-product of this process is that the patient experiences support and increased feelings of self-worth Individuals are encouraged to test new and more successful patterns of relating and adapting to the stress they experience.

Nurses play a vital role as therapists and also as co-ordinators of the practical issues related to the running of the groups.

\section{Evocative techniques}

As the name infers, these are various techniques designed to evoke feelings in the patient in order to facilitate self-expression and self-exploration aimed at achieving greater self-awareness. The teachings of Gestalt therapy are drawn upon in order to provide the patient with experiential learning situations in which he increases knowledge of himself. Perls ${ }^{10}$ states that With this improved orientation he is in a better position to cope with the situation by mobilizing his own resources. He no longer reacts with fixed responses and preconceived ideas. He doesn't cry for environmental support because he can do for himself. He no longer lives motivated by fears of impending catastrophies. He can now assess reality by experimenting with possibilities.

The team relies heavily on the skills of the psychiatric nurses and the occupational therapist to implement these techniques. Various media such as art, poetry, movement or a game are used to achieve the abovementioned goals. Further discussion of evocative techniques is not possible in this article but an example may clarify the technique.

A popular evocative technique is the guided fantasy. The patients are helped to relax and then told to fantasise a particular situation. They may then be required to draw or describe their fantasy.

This method of self-exploration through creative experience promotes expressiveness which may otherwise never occur as much unconscious material enters into the patient's realm of experiencing in this way. The group, under the guidance of the nurses and occupational therapist, reflects back to the patient their perception of his experience which he may either own or discard.

\section{Role-play}

Psychodrama and role-playing are group techniques designed to help patients to act out interpersonal and intrapersonal situations and conflicts rather than to just verbalise them.
These techniques facilitate the development of personal awareness and interpersonal sensitivity with regard to both the objective facts of external reality and aspects of internal experiences such as fantasy. ${ }^{2}$ An experiential learning situation is created for the patient by simulating a situation in his life and using strategies such as role reversal, sculpting or providing an alter ego. Thus a bridge is offered between thought and action in a safe environment in which the patient can feel free to experiment. Nurses function as co-directors or directors or they may be called upon by the patient to participate in the role-play.

\section{Social skills}

Certain patients are selected to attend a course of six sessions in social skills which is run by the nurses. The aim of the course is to improve nonverbal and verbal communication skills as well as to help the patient to be more assertive. The format of each session is flexible but usually consists of a discussion followed by rolepractising of the social situations in which the patients have difficulty. The latter is taped on audio-visual apparatus and then played back so that the patient can see where improvement in his social behaviour is necessary. Social skills has proven a valuable aid to therapy and is essentially a lighthearted fun activity which is of importance to the patients for future social functioning.

\section{Family intervention}

Family therapy in the unit is primarily the realm of the psychiatric social worker. However, nurses are constantly interacting with the families of patients and form an inportant link between families and the team after hours. When the nurse is allocated to a special patient programme it is important for her to liaise with the family of the patient, offering support and promoting understanding. In this way any undermining of the patient's treatment through lack of understanding is avoided.

\section{COMMUNITY WORK}

The nurse interacts with the patients more than any other team member and the responsibility of fostering and maintaining a community mindedness is largely hers. This means that the nurses not only ensure that the ward runs smoothly on a day-today living together basis, but they also see to it that the atmosphere in the ward is one conducive to therapy. Opportunity is provided on the patient's 
programme for the community to share and work together. In community work settings the nurse continues to function as a therapist by recognising patient's use of defence mechanisms and clarifying and interpreting their underlying anxieties.

\section{Feel wheel}

Each morning the nurse and patients get together in the lounge to share how they are feeling by pinning their name on the wheel of feelings. Thus each member of the community is made aware of the emotional state of the others and the climate for the day is set on a feeling level.

\section{Combined group}

For this group all team members and patients gather to share and discuss various issues, particularly those relevant to the atmosphere of the community. In this way it is hoped to establish a trusting climate with open communication which allows for healthy interpersonal relationships between staff and patients and amongst the patients themselves.

\section{Administration meeting}

Here practical issues concerning the ward are dealt with. A duty such as washing dishes and watering flowers is allocated to each patient. A patient is elected to act as a representative and also to ensure that the allocated tasks are completed. The way in which a patient carries out his duty is an important source of clinical data. Complaints and suggestions are also dealt with. This meeting is conducted by the patients. Nurses and the occupational therapist are present in an advisory capacity.

\section{Goals}

With the assistance of the other patients each patient is provided with the opportunity to set a tangible and an intangible goal for himself for the week. This provides the patient with a concrete direction in his treatment and a criterium whereby he can judge his own progress. Once again the nurse presides at the meeting in an advisory capacity.

\section{Individual Activities}

Sport, exercises, games and relaxation provide patients with the opportunity to use socially acceptable means of releasing aggression and tension. These activities are a welcome relief for the patient from the constant focus on problems. Nurses may either conduct or participate in all these activities.

Although most patients go out over the weekend, time is allocated for a community outing. This outing is an important indication to the team regarding the patient's ability to cope in social situations. Nurses and the occupational therapist accompany patients on these outings.

\section{CONCLUSION}

In an article reviewing psychiatric nursing in South Africa, C.I. Röscher indicated the importance of psychiatric nurses being able to function as therapists and thus taking their place as fully fledged members of the multidiscipliniary team. Marks et al (5,p 156-160) reported on research conducted on the psychiatric nurse as therapist, which suggests that using psychiatric nurses as skilled therapists could ease the current critical shortage of treatment personnel in psychiatry. The authors believe that not only is manpower shortage relieved, but functioning as a therapist accords the nurse greater job satisfaction. The role of the nurse in the unit described has been allowed to develop to its present extent as a result of the combination of highly motivated predecessors and an enthusiastic team leader whose belief in the capabilities of the psychiatric nurses has offered an incentive to the nurse's growth as therapists. In addition, the acceptance of the nurse as a therapist in her own right by other team members was a prerequisite.

The primary motivating factor for writing this article has been the tremendous sense of job satisfaction that the authors have gained in their role as nurse therapists in a multidiscipliniary team.

\section{ACKNOWLEDGEMENTS}

The authors would like to thank I)r. Eleanor Nash for her enthusiasm and guidance and all the members of the psychotherapeutic team for their encouragement and support. They would like to express their appreciation to Dr. H. Reeve Sanders, Medical Superintendent, and Miss I..J. du Preez, Chief Matron, for granting permission to publish this article.

\section{BIBLIOGRAPHY AND REFERENCES}

Barnea, Iondon. 1968. Parts 1, 11, III

2. Blatner, H.A. Acting in: practical application of psy. chodramatic methods. Springer. New York. 1973.

3. Brammer, L.M.; Shostrom E.L. Therapeutic psy. chology. Prentice Hall. New Jenney. 1968. 3rd Ed.

D'Arcy, L. Anorectic behaviour modtifation, Cap Town. 1979. Un published paper.

5. Marks, I.M.: Connolly, J.: Hallam, R.S. Psychiatric Marks, I.M.: Connolly, J.: Hallam, R.S. Psychiatric
nurse as therapist", British Medical dournal. Vol. 3. 1973. Pp 156-160.

6. Marram, G.D. The group approach to nursing prac tice, C.V. Mosby. Saint Louis. 1973.

. Moros H. ATherapeutic community in the sethug of a psychiatric teaching hospilal. Part I. S.A. Medical Journal A pril 1967. Pp 351-355.

8. Nash, Eleanor: A resumee of proceedings of the Cas sell Hospital Diamond dubilee. United Kingdom. 1980, unpubliahed paper.

9. Nash, Eleanor: Report on a tusit to sì therapeutic communities in the l'nited Kingdom. United King dom. 1979. Unpublished paper.

10. Perls, F.G. Gestalt therapies and human potentialities In Gestalt is. Stevens J.O. (Ed. Real Penple Press. Utah. 1975.

11. Roscher, C.I. Psigiatriese verpleging in Suid-A frika: 'n oorsig, S.A. Nursing Journal. Vol. 42 No. 5. May 1975 $11-14$

12. Stuart, G.W.; Sundine S.J. Principles and practice of psychiatric nursing. C.V. Moshy. Saint Louis. 1979 13. Stevens J.O. Auareness. Real People Preas. Utah 1971

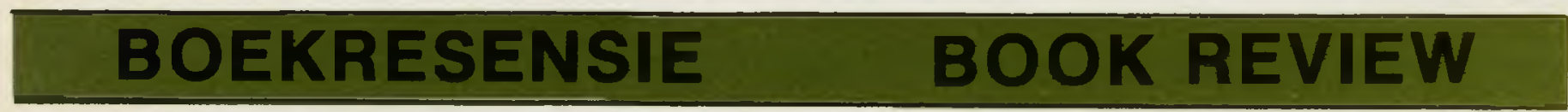

\section{VERLOSKUNDE \\ deur C. F. Slabber et al \\ Human en Rousseau. Kaapstad. 1980. Prys ongeveer R36,50.}

Hier het ons uiteindelik 'n ideale verwysingsbron vir die Afrikaanse verloskunde-student, met inligting in verband met die nuutste ontwikkelings soos sonarondersoeke, kardiotokografie en vele ander onderwerpe.

Ek dink egter nie dat dit in al die behoeftes van 'n student vroedvrou in haar basiese opleiding voldoen nie, omdat sommige onderwerpe redelik tegnies bespreek word, en andere weer nie genoeg inligting spesifiek vir haar doeleindes verskaf nie.

Dit behoort egter vir enige persoon wat die gevorderde kursus in verloskunde en neonatalogie volg sowel as doserende personeel van onskatbare waarde te wees.

M. E. JORDAAN.
MEDICINE OUT OF CONTROL

Richard Taylor

Macmillan. London. 1980.

Approximate Price: R11,60
I find the abovementioned book fascinating yet formidable. As the author describes it, diseases are more than mere biological and physical phenomena, they are events within the specific social context, and involve a variety of people in different social roles.

Many of the situations described by the author, are alarming because they are so ridiculously true.

This is a book which both the medical and lay person would find informative as well as entertaining reading. 